\title{
KARAKTERISTIK DAN MODEL MATEMATIKA KURVAPENGERINGAN RUMPUT LAUT Eucheuma cottonii
}

\section{Characteristics and Mathematical Model of Drying Curve of Eucheuma cottonii Seaweed}

\author{
Diini Fithriani ${ }^{1 *}$, Luthfi Assadad ${ }^{2}$ dan Zaenal Arifin Siregar ${ }^{2}$ \\ ${ }^{1}$ Pusat Penelitian dan Pengembangan Daya Saing Produk dan Bioteknologi Kelautan dan Perikanan, \\ JI. KS Tubun, Petamburan VI Slipi, Jakarta Pusat, Indonesia \\ ${ }^{2}$ Loka Penelitian dan Pengembangan Mekanisasi Pengolahan Hasil Perikanan, \\ JI. Imogiri Barat Km 11,5, Bantul, DI Yogyakarta, Indonesia \\ * Korespondensi Penulis: diini_fithriani@yahoo.com \\ Diterima: 21 Agustus 2016; Disetujui: 15 Nopember 2016
}

\begin{abstract}
ABSTRAK
Studi ini dimaksudkan untuk menginvestigasi karakteristik dan model matematika kurva pengeringan rumput laut Eucheuma cottonii. Hasil penelitian ini diharapkan dapat digunakan untuk perancangan alat pengering rumput laut yang efisien. Pengeringan E.cottonii dilakukan dengan menggunakan alat pengering laboratorium terkendali yang dilengkapi dengan sistem akuisisi data dengan kecepatan udara $0,5 \mathrm{~m} /$ detik. Empat variasi $\mathrm{RH}$ yang dilakukan pada suhu $50{ }^{\circ} \mathrm{C}$ adalah $30 \%, 40 \%, 50 \%$ dan $60 \%$ serta empat variasi suhu yang dilakukan pada $\mathrm{RH} 40 \%$ adalah $40^{\circ} \mathrm{C}, 50^{\circ} \mathrm{C}, 60^{\circ} \mathrm{C}$ dan $70^{\circ} \mathrm{C}$. Tiga model pengeringan yang diuji adalah model Newton, Henderson \& Pabis dan Page. Simulasi model yang paling tepat ditentukan berdasarkan nilai $\mathrm{R}^{2}$ yang paling tinggi, serta nilai sum square error (SSE) dan root mean square error RMSE yang paling rendah. Laju pengeringan lapis tipis rumput laut E.cottonii umumnya berada pada periode laju menurun. Hal ini sesuai dengan karakteristik pengeringan bahan-bahan biopolimer yang umumnya berlangsung dengan laju menurun. Hasil penelitian menunjukkan bahwa penurunan $\mathrm{RH}$ cukup efektif dalam menurunkan kadar air dibandingkan peningkatan suhu. Pada $\mathrm{RH}$ rendah yaitu $30 \%$ suhu $50{ }^{\circ} \mathrm{C}$, penurunan kadar air 50\% dicapai dalam waktu 80-85 menit jauh lebih cepat dari $\mathrm{RH} 60 \%$ suhu $50{ }^{\circ} \mathrm{C}$ yaitu $165-170$ menit. Pada suhu tertinggi yaitu $70{ }^{\circ} \mathrm{C} \mathrm{RH} 40 \%$ penurunan kadar air 50\% dicapai dalam waktu 90 menit selisih 15 menit lebih cepat dibandingkan suhu terendah yaitu $40{ }^{\circ} \mathrm{C} \mathrm{RH} 40 \%$. Kajian ini mendapati model pengeringan E.Cotonii yang paling sesuai adalah model pengeringan Page dengan nilai $R^{2}, R^{2}$ terkoreksi, SSE and RMSE berturut - turut sebesar 0,98-0,99;0,96-0,98;0,0002-0,0126 dan 0,0002-0,0206.
\end{abstract}

KATAKUNCI： model matematika, pengeringan, rumput laut, Eucheuma cottonii

\begin{abstract}
This study is intended to know the drying characteristics and drying curve mathematical models of Eucheuma cottonii seaweed. The results of this study are expected to be used for the design seaweed efficient dryer. E. cottonii was dried using a laboratory controlled dryer with data acquistion with air velocity of $0,5 \mathrm{~m} / \mathrm{s}$. Four variations of $\mathrm{RH}$ observed at temperature $50^{\circ} \mathrm{C}$ were $30 \%, 40 \%$, $50 \%$ and $60 \%$ and four variations of temperature observed at $\mathrm{RH} 50 \%$ were $40{ }^{\circ} \mathrm{C}, 50^{\circ} \mathrm{C}, 60^{\circ} \mathrm{C}$ and $70^{\circ} \mathrm{C}$. Three drying models were tested, i.e Newton, Henderson \& Pabis and Page models. Simulation of the most appropriate model is determined based on the highest $R^{2}$, as well as the lowest sum square error (SSE) and root mean square error (RMSE). The drying rate thin layer of seaweed E.cottonii generally at the falling rate period. This is in accordance with the drying characteristics of the biopolymer materials which generally take place at a rate decrease. The results showed that the decrease in $\mathrm{RH}$ quite effective in lowering levels of moisture content compared to the increase in temperature. At low $\mathrm{RH}$ at $30 \%$ and temperature of $50{ }^{\circ} \mathrm{C}, 50 \%$ moisture reduction achieved within 80-85 minutes much faster than $\mathrm{RH} 60 \%$ temperature $50{ }^{\circ} \mathrm{C}$ that is $165-170$ minutes. At the highest temperature $70^{\circ} \mathrm{C}$ and $\mathrm{RH} 40 \%$ reduction in water content of $50 \%$ is achieved within 90 minutes just difference 15 minutes faster than the lowest temperature that is $40^{\circ} \mathrm{C}$ and $\mathrm{RH} 40 \%$. The most suitable drying model for $\underline{E}$ cottonii was the Page model with $R^{2}$, SSE and RMSE values of 0.98-0.99;0.96-0.98; 0.0002-0.0126 and 0.0002-0.0206 respectively.
\end{abstract}

KEYWORDS: mathematical model, drying, seaweed, Eucheuma cottonii 


\section{PENDAHULUAN}

Rumput laut Eucheuma cottonii biasanya dipanen dengan kadar air yang sangat tinggi, dapat mencapai $93 \%$, karena itu proses pengeringan adalah proses penting bagi rumput laut guna menurunkan kadar air. Kadar air yang baik untuk rumput laut kering adalah di bawah 35\% (SNI 32\%) (Wibowo, Peranginangin, Darmawan \& Hakim, 2014). Kadar air maksimal rumput laut di tingkat petani adalah $40 \%$ dan lebih disukai 35\% (McHugh, 2006). Penurunan kadar air adalah salah satu teknik tertua untuk pengawetan makanan (Saeed, Sopian \& Abidin, 2008). Metode mekanik dan panas adalah dua metode dasar untuk menurunkan kadar air pada material padat (Karimi, 2010).

Aspek yang penting dari teknologi pengeringan adalah pemodelan matematika dari proses pengeringan. Prinsip pemodelan didasarkan pada satu set persamaan matematika yang dapat secara baik menjelaskan suatu sistem. Solusi dari persamaan ini harus menyediakan perhitungan parameter proses sebagai fungsi waktu pada setiap titik dalam pengering yang didasarkan pada kondisi primer. Penggunaan model simulasi penting untuk memprediksi performansi sistem pengeringan (Taheri-Garravanda, Rafieea \& Keyhania, 2011). Tujuan pemodelan matematika adalah untuk memudahkan dalam memilih kondisi operasi yang paling cocok dan kemudian mendisain peralatan pengeringan dan ruang pengeringan sesuai dengan kondisi operasi yang diinginkan (Kaleta \& Gornichi, 2010).

Tiga model matematika yang digunakan dalam penelitian ini adalah model Newton, model Henderson dan Pabis dan model Page. Ketiga model dipilih sebagai pembanding dengan data percobaan karena model-model tersebut merupakan model yang umum digunakan untuk menggambarkan karakteristik pengeringan lapisan tipis dan merupakan penyederhanaan model teoritis yang diperoleh dari persamaan difusi (Hukum II Fick). Model Newton merupakan sebuah model matematika pengeringan lapisan tipis yang juga disebut model Lewis. Lewis mendeskripsikan bahwa perpindahan air dari makanan dan bahan pangan dapat ditunjukkan dengan analogi aliran panas dari tubuh ketika tubuh direndam dalam cairan dingin (Kashaninejad, Mortazavi, Safekordi, \& Tabil, 2007).

Model Henderson \& Pabis telah digunakan pada model pengeringan lapisan tipis untuk berbagai produk pertanian di antaranya digunakan untuk model pengeringan jagung, gandum, beras kasar, kacang dan umbi umbian (Kashaninejad et al., 2007).

Model Page merupakan model yang dimodifikasi dari model Lewis. Page menyarankan model ini dengan tujuan untuk mengoreksi kekurangankekurangan dari model Lewis (Kashaninejad et al., 2007). Model Page telah menghasilkan simulasi yang sesuai untuk menjelaskan pengeringan berbagai produk pertanian dan lebih mudah digunakan dibandingkan dengan persamaan lainnya. Perpindahan uap air melalui difusi secara teoritis lebih sulit serta memerlukan waktu komputasi dalam proses pemasangan data (Yadollahinia, Omid \& Rafiee 2008).

Kriteria pembanding yang dipakai untuk menentukan model persamaan yang terbaik selain koefisien determinasi $\left(\mathrm{R}^{2}\right)$, adalah sum square error (SSE) dan root mean square error (RMSE) (Yadollahinia et al., 2008; Taheri-Garavanda et al., 2011). Nilai $R^{2}$ digunakan sebagai kriteria pembanding untuk menentukan ketepatan model. Nilai RMSE merupakan deviasi antara nilai prediksi dari model dengan nilai hasil percobaan. Semakin tinggi nilai $R^{2}$ dan semakin rendah nilai SSE dan RMSE maka model akan semakin tepat.

Persamaan pengeringan lapis tipis dapat digunakan untuk memprediksi kurva pengeringan secara umum. Model matematik dan simulasi pengeringan dengan kondisi yang berbeda penting untuk memperoleh kontrol yang lebih baik dalam unit operasi pengeringan dan perbaikan keseluruhan dari kualitas akhir produk (Goyal, Kingsly, Manikantan \& Ilyas, 2007). Berbagai penelitian telah menuliskan model matematika untuk pengeringan lapis tipis seperti pada wortel (Aghabashlo, Kianmehr \& Khani, 2008; Setyopratomo, 2012), buah kesemek (Doymaz, 2012), plum (Goyal et al., 2007), apel (Meisami-asl \& Rafiee, 2009), tomat (Taheri-Garravand et al., 2011), jamur oyster (Tulek, 2011), rapeseed (Duc, Han, Keumb \& Keum, 2011), ikan kembung (Hawa, Sumardi \& Sari, 2009). Beberapa penelitian tentang pengeringan rumput laut telah dilakukan. Fudholi et al. (2011) telah mempelajari efek temperatur dan kelembaban pada rumput laut Gracillaria cangii dan juga mempelajari kinetika pengeringan rumput laut E.cottonii pada kelembaban rendah.

Tujuan dari penelitian ini adalah untuk menginvestigasi karakteristik dan model matematika kurva pengeringan rumput laut $E$. cottonii. Hasil penelitian ini diharapkan dapat digunakan untuk perancangan alat pengering rumput laut yang efisien.

\section{BAHAN DAN METODE}

\section{Bahan dan Alat}

Bahan utama yang digunakan dalam penelitian ini adalah rumput laut E.cottonii segar yang dibeli dari pengepul di Desa Lontar, Serang, Banten. Rumput laut yang telah dibeli, ditransportasikan dan disimpan 


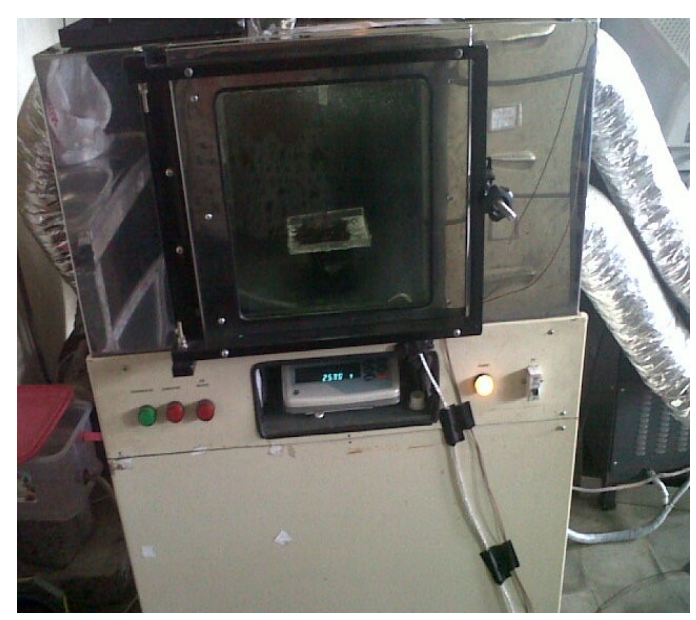

Gambar 1. Alat pengering skala laboratorium yang dilengkapi dengan sistem akuisisi data di Laboratorium Pindah Panas dan Massa , Departemen Teknik Mesin dan Biosistem, IPB

Figure 1. Laboratory Scale Dryer with Data Acquistion at Heat and Mass Transfer Laboratory, Department of Mechanical and Biosystem Engineering, IPB

pada kondisi dingin $\pm 8^{\circ} \mathrm{C}$ sebelum dikeringkan. Jeda waktu antara sampling E.cottonii dan awal penelitian pengeringan adalah 2 hari dan lama waktu penelitian adalah 2,5 minggu.

Alat-alat yang digunakan dalam penelitian ini adalah alat pengering skala laboratorium yang dilengkapi dengan sistem akuisisi data di Laboratorium Pindah Panas dan Massa, Departemen Teknik Mesin dan Biosistem, Fakultas Teknologi Pertanian, IPB, oven Ikeda Scientific SS204D, desikator, seperangkat komputer, anemometer Kanomax A541.

\section{Pengoperasian Alat}

Pada setiap percobaan, alat pengering dihidupkan sekitar setengah hingga satu jam sebelum percobaan dimulai, untuk menstabilkan ruang pengering dengan kondisi percobaan yang diinginkan. Kondisi percobaan yang dilakukan pada penelitian ini dijelaskan pada Tabel 1, di mana perlakuan pada proses pengeringan E.cottonii terdiri atas dua faktor, yaitu faktor suhu dan faktor $\mathrm{RH}$. Suhu yang divariasikan $\mathrm{RH}$ nya adalah suhu $50^{\circ} \mathrm{C}$ sedangkan $\mathrm{RH}$ yang divariasikan suhunya adalah $40 \%$ yang merupakan suhu dan $\mathrm{RH}$ rata-rata yang dipergunakan dalam pengeringan rumput laut. Masing-masing uji coba dilakukan pada laju udara pengering $0,5 \mathrm{~m} /$ detik.

Suhu pengering yang digunakan dalam penelitian ini adalah $40-70^{\circ} \mathrm{C}$. Sedangkan $\mathrm{RH}$ yang dipergunakan dalam penelitian ini adalah $30-60 \%$. Pengeringan bahan hasil pertanian menggunakan aliran udara pengering yang baik adalah antara $45^{\circ} \mathrm{C}$ sampai $75^{\circ} \mathrm{C}$. Pengeringan dengan suhu di bawah $45^{\circ} \mathrm{C}$ menyebabkan mikroba dan jamur yang merusak produk masih hidup, sehingga daya awet dan mutu produk rendah. Namun pada suhu udara pengering di atas $75^{\circ} \mathrm{C}$ menyebabkan 8 struktur kimiawi dan fisik produk rusak, karena perpindahan panas dan massa air yang berdampak perubahan struktur sel (Setiyo, 2003).

Massa, suhu, dan kelembaban udara pengering dicatat datanya setiap 5 menit selama pengeringan.

Tabel 1.Kondisi percobaan pengeringan

Table1. Drying experiment condition

\begin{tabular}{ccccc}
\hline \multirow{2}{*}{ Suhu/Temperature } & $\left({ }^{\circ} \mathrm{C}\right)$ & \multicolumn{5}{c}{ Kelembaban relatif/ Relatif humidity (RH) (\%) } \\
\cline { 2 - 5 } & $\mathbf{3 0}$ & $\mathbf{4 0}$ & $\mathbf{5 0}$ & $\mathbf{6 0}$ \\
\hline 40 & & $\mathrm{~V}$ & & \\
50 & $\mathrm{~V}$ & $\mathrm{~V}$ & $\mathrm{~V}$ & $\mathrm{~V}$ \\
60 & & $\mathrm{~V}$ & & \\
70 & & $\mathrm{~V}$ & & \\
\hline
\end{tabular}


Proses pengeringan berlangsung sampai massa E. cottonii konstan. Perubahan massa sampel diukur langsung secara otomatis dengan menggunakan timbangan digital GF-3000 A\&D (kapasitas sampai dengan $3000 \mathrm{~g}$ dengan ketelitian $0,01 \mathrm{~g}$ ). Pada saat penimbangan, blower secara otomatis akan mati agar tidak ada udara yang masuk ke ruang pengering.

Parameter pengamatan dan pengolahan data dalam penelitian ini meliputi:

a. Perubahan massa $E$. cottonii setiap 5 menit selama pengeringan berlangsung

b. Kadar air akhir/kadar air kesetimbangan

Pengukuran kadar air akhir dilakukan setelah massa bahan konstan. Pengukuran kadar air akhir dilakukan dengan menggunakan oven pengering secara triplo (BSN, 2006).

c. Perubahan kadar air selama pengeringan berlangsung

Perubahan kadar air (per 5 menit) selama pengeringan diolah berdasarkan data kadar air akhir dan data perubahan massa E.cottonii setiap 5 menit. Adapun persamaannya adalah sebagai berikut:

Berat $(t+5)=$ Berat $(t) \times \frac{100-\text { kadar air }(t)}{100-\text { kadar air }(t+5)}$

Keterangan :

$\mathrm{t}=$ menit ke $\mathrm{t}$

$\mathrm{t}+5=$ menit ke $\mathrm{t}+5$ menit d. Laju Pengeringan (\% bk/menit).

Laju pengeringan ditentukan dengan menghitung selisih berat kering bahan selama pengeringan terhadap waktu.

e. Moisture Ratio (MR)

Moisture Ratio (MR) dapat dihitung menggunakan persamaan berikut (Ibrahim, Sopian, \& Daud, 2009)

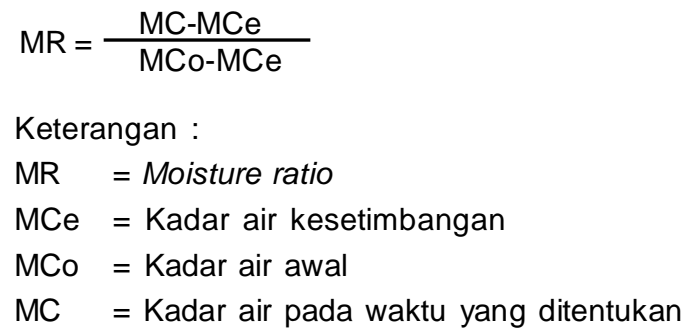

\section{Model Matematika Pengeringan}

Model matematika pengeringan E.cottonii dihitung berdasarkan data MR hasil percobaan. Data MR hasil percobaan dihubungkan terhadap waktu didalam grafik dan dihitung persamaan matematikanya hingga menghasilkan konstanta pengeringan $\mathrm{k}$, a dan $\mathrm{n}$. Nilai $k$, a dan $n$ hasil pemodelan digunakan untuk menghasilkan nilai MR model (Yadollahinia \& Rafiee, 2008). Analisis regresi exponensial dilakukan dengan bantuan Microsoft Excel spreadsheet (Microsoft Office 2007).

Tabel 2. Model matematika yang digunakan untuk menggambarkan pengeringan lapis tipis Table 2. Mathematical models used to describe thin layer drying

\begin{tabular}{|c|c|c|c|}
\hline Model/Model & \multicolumn{2}{|c|}{ Persamaan/Equation } & Pustaka/Reference \\
\hline Lewis & $\mathrm{MR}=\exp (-\mathrm{kt})$ & $\ln (M R)=-k t$ & $\begin{array}{l}\text { Kabganian, Carrier \& Sokhansanj, } \\
\text { 2002; Krokida, Maroulis \& Kremalis } \\
\text { 2002; Yaldýz \& Ertekýn, } 2001\end{array}$ \\
\hline Page & $M R=\exp (-k t n)$ & $\ln (-\ln (M R))=\ln (k)+n \ln (t)$ & $\begin{array}{l}\text { Cronin \& Kearny, 1998; Gupta, Ahmet, } \\
\text { Shivhare \& Raghavan, 2002; Kabganian } \\
\text { et al., 2002; Midilli, Kucuk \& Yapar, 2002; } \\
\text { Yaldýz \& Ertekýn, } 2001\end{array}$ \\
\hline Henderson and Pabis & $M R=a \exp (-k t)$ & $\ln \mathrm{MR}=-\mathrm{kt}+\ln (\mathrm{a})$ & Kabganian et al., 2002 \\
\hline
\end{tabular}

\footnotetext{
Catatan/Note :

MR = Moisture Ratio

$\mathrm{k}, \mathrm{a}, \mathrm{n}=$ konstanta pengeringan
} 
Tabel 3. Ketidakpastian parameter selama pengeringan Eucheuma cottonii Table 3. Uncertainties of the parameters during drying Eucheuma cottonii

\begin{tabular}{lcc}
\hline \multicolumn{1}{c}{ Parameter/Parameters } & Satuan/Unit & Keterangan/Note \\
\hline $\begin{array}{l}\text { Ketidakpastian pengukuran suhu/Uncertainty of the measurement } \\
\text { of temperature (maksimal/maximal) }\end{array}$ & $\%$ & 1 \\
$\begin{array}{l}\text { Ketidakpastian pengukuran Kelembaban Relatif/ Uncertainty of } \\
\text { the measurement of relative humidity (maksimal/maximal) }\end{array}$ & $\%$ & 3 \\
\hline
\end{tabular}

Tabel 4. Perbandingan data hasil pengukuran dengan yang diharapkan pada seting alat data Table 4. Comparison of measured data to the expected data at instrumental set up

\begin{tabular}{lcccc}
\hline \multicolumn{1}{c}{ RH yang diharapkan/Expected $\mathbf{R H}$} \\
\hline Suhu yang diharapkan/Expected temperatures & $\mathbf{4 0}{ }^{\circ} \mathbf{C}$ & $\mathbf{5 0}{ }^{\circ} \mathbf{C}$ & $\mathbf{6 0}{ }^{\circ} \mathbf{C}$ & $\mathbf{7 0}{ }^{\circ} \mathbf{C}$ \\
\hline Suhu aktual/Actual temperature $\left({ }^{\circ} \mathrm{C}\right)$ & $40.5 \pm 0.3$ & $50.6 \pm 0.8$ & $60.2 \pm 0.4$ & $69.8 \pm 0.4$ \\
RH aktual/Actual $R H(\%)$ & $40.1 \pm 0.7$ & $40.0 \pm 0.2$ & $39.3 \pm 0.5$ & $37.6 \pm 3.0$ \\
\hline Suhu yang diharapkan/Expected temperatures & \multicolumn{5}{c}{$\mathbf{5 0}{ }^{\circ} \mathbf{C}$} \\
\hline \multicolumn{1}{r}{$\mathbf{R H}$ yang diharapkan $/$ Expected $\mathbf{R H}$} & $\mathbf{3 0 \%}$ & $\mathbf{4 0 \%}$ & $\mathbf{5 0 \%}$ & $\mathbf{6 0 \%}$ \\
\hline Suhu aktual/Actual temperature $\left({ }^{\circ} \mathrm{C}\right)$ & $50.3 \pm 0.2$ & $50.6 \pm 0.9$ & $50.5 \pm 0.3$ & $50.6 \pm 0.2$ \\
RH aktual/Actual $R H(\%)$ & $30.0 \pm 0.3$ & $40.1 \pm 0.7$ & $49.5 \pm 2.0$ & $59.0 \pm 3.0$ \\
\hline
\end{tabular}

\section{HASIL DAN PEMBAHASAN}

\section{Akuisisi dan kehandalan data}

Kesalahan dan ketidakpastian dapat muncul dari pemilihan instrumen, kondisi, kalibrasi, lingkungan, observasi, pembacaan dan rencana pengujian (Apkinar, Midilli \& Bicer, 2003). Dalam penelitian pengeringan $E$. cottonii, suhu, kelembaban relatif, dan penurunan berat diukur dengan alat-alat pengering di laboratorium yang dilengkapi dengan sistem akuisisi data. Selama pengukuran, ketidakpastian pengukuran disajikan pada Tabel 3. Adapun hasil rata-rata dan standar deviasi $\mathrm{RH}$ dan temperatur dari masing-masing percobaan disajikan pada Tabel 4 .

Secara umum suhu dan kelembaban relatif $(\mathrm{RH})$ selama penelitian cukup stabil dan sesuai dengan pengaturan alat. Nilai rata-rata ketidakpastian pengukuran untuk suhu adalah $1 \%$ dan nilai rata rata ketidakpastian pengukuran untuk $\mathrm{RH}$ adalah $3 \%$ Ketidakpastian pengukuran pada $\mathrm{RH}$ terbesar, terjadi pada pengaturan suhu tertinggi yaitu $70^{\circ} \mathrm{C}, \mathrm{RH} 40 \%$. Kesulitan alat mencapai $\mathrm{RH} 40 \%$ dapat dipahami karena semakin tinggi suhu, maka $\mathrm{RH}$ cenderung semakin rendah. Ketidakpastian sampel dihindari dengan penjagaan sampel selama transportasi dan penyimpanan. Sebelum percobaan sampel disimpan pada suhu dingin untuk menghindari kerusakan.

\section{Karakteristik Pengeringan}

\section{Kurva kadar air terhadap waktu}

Pengaruh kondisi pengeringan terhadap penurunan kadar air basis kering $E$. cottonii ditunjukkan pada Gambar 2. Penurunan kadar air terjadi dengan cepat pada menit-menit awal pengeringan, dan melambat seiring bertambahnya waktu pengeringan.

Dalam penelitian ini diketahui bahwa penurunan $\mathrm{RH}$ lebih efektif dalam menurunkan kadar air dibandingkan peningkatan suhu. $\mathrm{Pada} \mathrm{RH}$ yang rendah yaitu $30 \%$, penurunan kadar air $50 \%$ dicapai dalam waktu 80-85 menit, 2 kali lipat lebih cepat dari $\mathrm{RH}$ $60 \%$ yaitu $165-170$ menit, sedangkan untuk menurunkan kadar air sebanyak $80 \%$ diperlukan waktu 180 menit, jauh lebih cepat dibandingkan $\mathrm{RH} 60 \%$ yaitu 380 menit. Pada suhu tertinggi yaitu $70{ }^{\circ} \mathrm{C}$ dibutuhkan waktu 90 menit untuk menurunkan kadar air sebanyak 50\%, dan 205 menit untuk menurunkan kadar air sebanyak $80 \%$, jika dibandingkan dengan suhu $40^{\circ} \mathrm{C}$ hanya selisih 15 menit lebih cepat pada penurunan kadar air 50\% dan 40 menit lebih cepat pada penurunan kadar air $80 \%$.

\section{Kurva laju pengeringan terhadap waktu}

Laju pengeringan menunjukkan banyaknya uap air yang diuapkan per satuan waktu. Laju pengeringan 


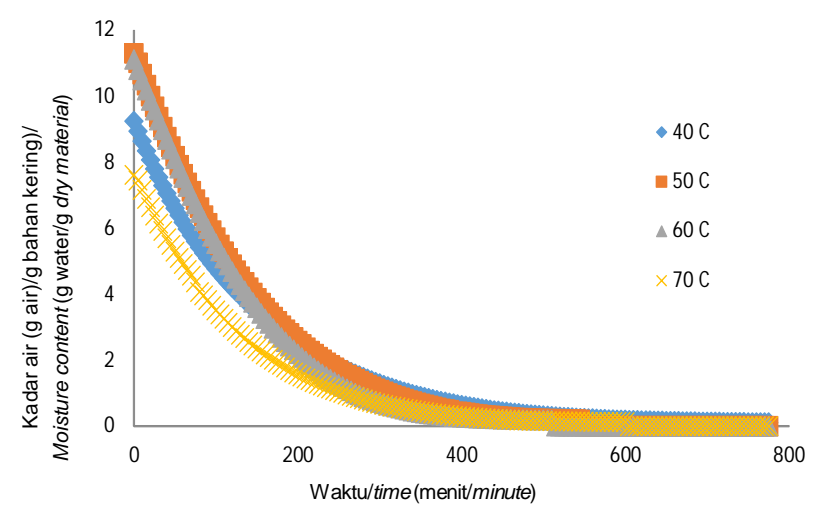

(a)

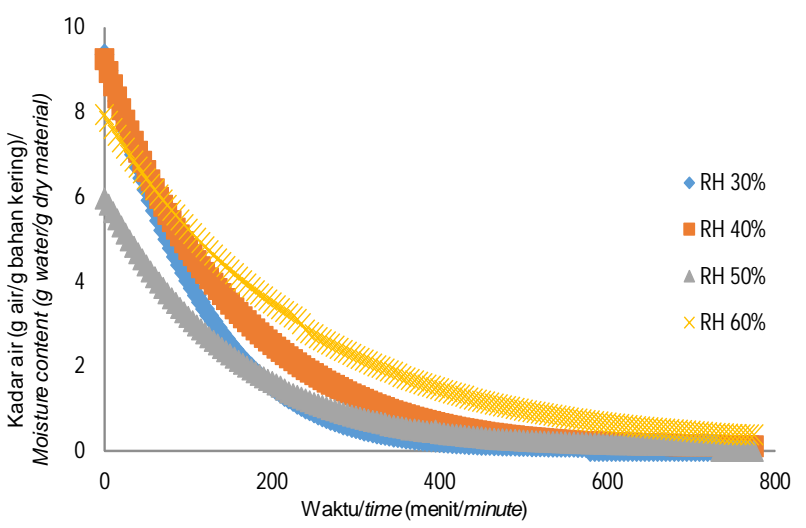

(b)

Gambar 2. Hubungan antara waktu dan kadar air pada (a) $\mathrm{RH} 40 \%$ (b) suhu $50^{\circ} \mathrm{C}$

Figure 2. Correlation between time and moisture content at (a) $R H 40 \%$ (b) temperature $50^{\circ} \mathrm{C}$

atau kecepatan pengeringan suatu bahan, dipengaruhi oleh sifat bahan dan kondisi operasi pengeringan. Kondisi operasi yang menjadi variabel pengeringan terdiri dari aliran gas pengeringan, suhu, tekanan operasi, kelembaban udara, arah aliran udara pengering dan waktu.

Gambar 3 dan 4 menunjukkan bahwa besaran laju pengeringan $E$. cottonii cenderung menurun seiring bertambahnya waktu, sehingga dapat dikatakan bahwa pengeringan rumput laut $E$. cottonii berada pada laju pengeringan menurun. Hasil yang sama untuk jenis tanaman yang berbeda yaitu tomat dan beberapa buah dan sayuran telah dilaporkan (Akanbi, Adeyemi \& Ojo, 2006; Akpinar, 2006). Dalam laju pengeringan menurun, proses difusi merupakan mekanisme fisik yang dominan dalam pergerakan kadar air di dalam bahan (Sinha, Hui, Özgül, Siddiq \& Ahmed, 2010).
Pada Gambar 4 tampak bahwa laju pengeringan pada tahap awal yaitu 10 menit pertama mengalami kenaikan kemudian setelah itu mengalami penurunan, ini menunjukkan bahwa pengeringan $E$. cottoniipada $\mathrm{RH} 40 \%$ dengan variasi suhu mengalami periode initial adjustment yaitu periode awal di mana laju pengeringan naik atau turun dengan cepat.

Dari Gambar 3 dan 4 terlihat bahwa nilai laju pengeringan pada tahap awal lebih tinggi daripada nilai laju pengeringan tahap akhir. Semakin tinggi laju pengeringan artinya jumlah yang diuapkan per menit semakin besar. Hal yang menjadi penyebab penurunan kadar air yang relatif besar di awal pengeringan adalah karena pada awal pengeringan kandungan air bebas yang berada di permukaan bahan masih tinggi sehingga terjadi perpindahan massa dari bahan ke udara dalam bentuk uap air sampai tekanan uap air pada permukaan menurun. Pada tahap berikutnya

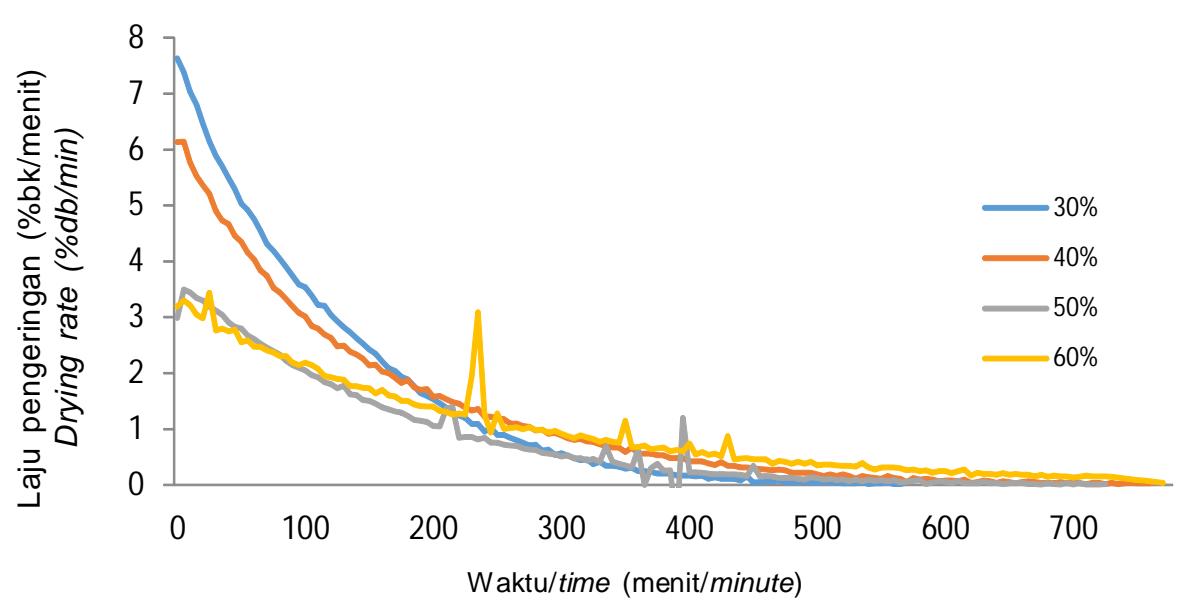

Gambar 3. Hubungan waktu dan laju pengeringan pada suhu $50^{\circ} \mathrm{C}$

Figure 3 . Corellation between time and drying rate at temperature $50^{\circ} \mathrm{C}$ 


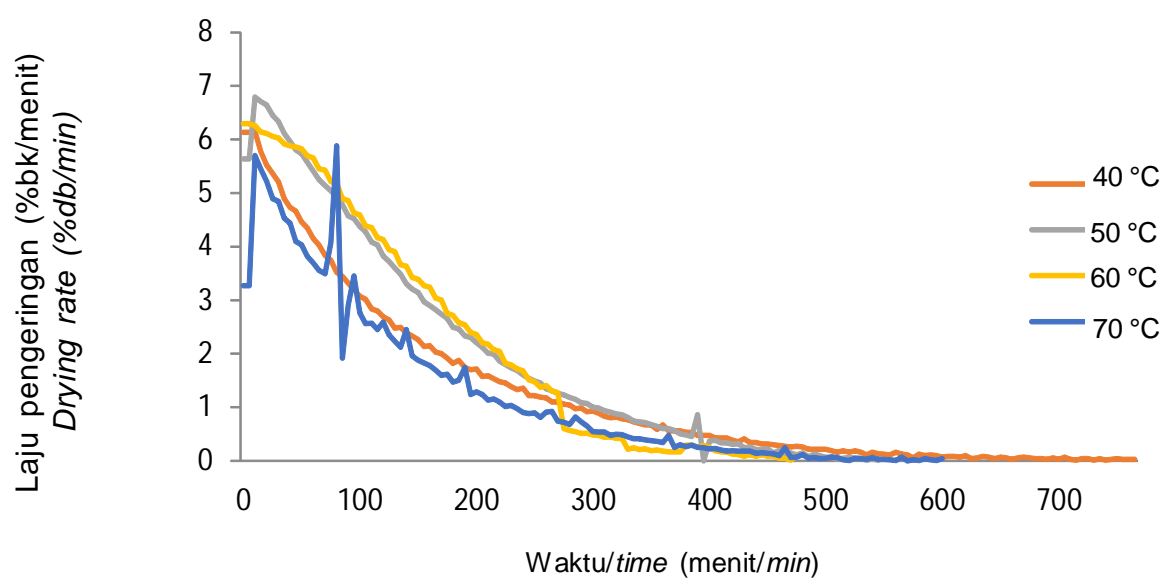

Gambar 4. Hubungan waktu dan laju pengeringan pada $\mathrm{RH} 40 \%$ pada berbagai variasi suhu

Figure 4.Correlation between dryng rate and time at $\mathrm{RH} 40 \%$ at various temperature

terjadi perpindahan air dari bahan ke permukaan secara difusi yang mengakibatkan penurunan massa air menjadi lebih lambat. Setelah air bahan semakin berkurang, maka tekanan uap air bahan akan menurun sampai terjadi keseimbangan dengan udara sekitarnya dan tidak terjadi perpindahan air lagi (Chen \& Mujumdar, 2009).

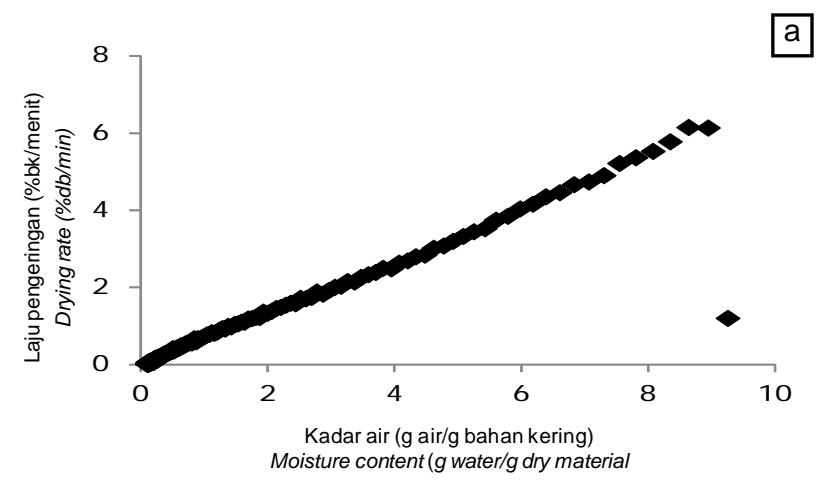

C

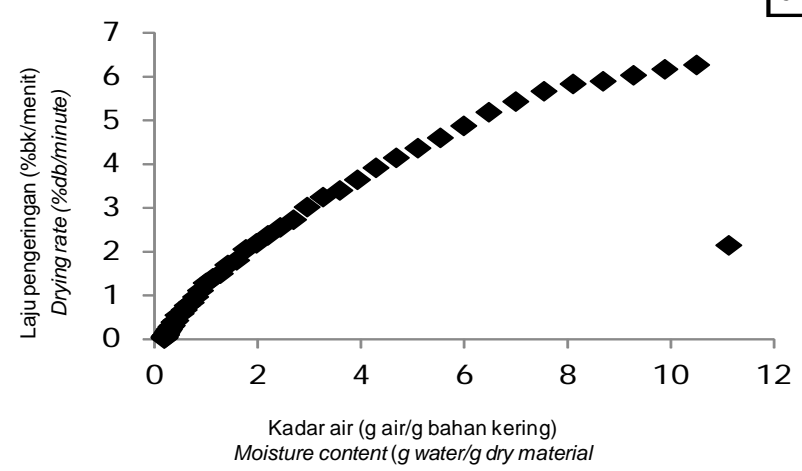

Proses pengeringan dengan laju pengeringan menurun sangat tergantung pada sifat-sifat alami bahan yang dikeringkan. Laju perpindahan massa selama proses ini dikendalikan oleh perpindahan internal bahan (Istadi, Sumardiono \& Anas, 2002). Pada Gambar 3, pada suhu $70{ }^{\circ} \mathrm{C}$, kurva suhu pengeringan tampak tidak stabil dan grafik laju

Gambar 5. Hubungan antara kadar air dan laju pengeringan pada $\mathrm{RH} 40 \%$ pada variasi suhu a) $40^{\circ} \mathrm{C}$, b) $50^{\circ} \mathrm{C}$, c) $60^{\circ} \mathrm{C}$, d) $70^{\circ} \mathrm{C}$

Figure 5. Correlation between moisture content and drying rate at $\mathrm{RH} 40 \%$ at various temperature a) $40{ }^{\circ} \mathrm{C}$, b) $\left.50^{\circ} \mathrm{C}, \mathrm{c}\right) 60^{\circ} \mathrm{C}$, d) $70^{\circ} \mathrm{C}$ 

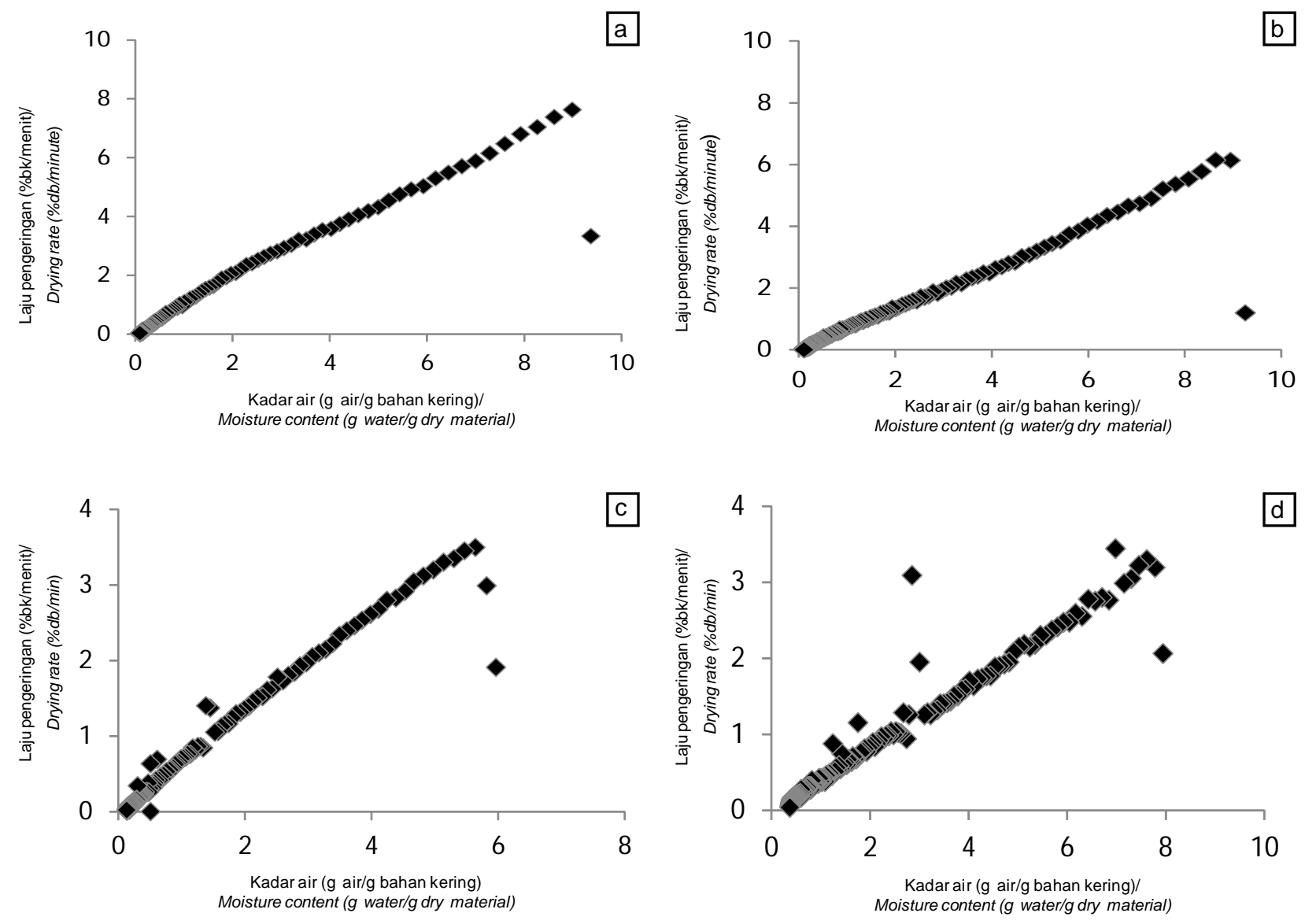

Gambar 6. Hubungan antara kadar air dan laju pengeringan pada suhu $50^{\circ} \mathrm{C}$ pada variasi $\mathrm{RH}$ a) $30 \%$, b) $40 \%$, c) $50 \%$, d) $60 \%$

Figure 6. Correlation between moisture content and dryng rate at temperature $50{ }^{\circ} \mathrm{C}$ at various $\mathrm{RH}$

a) $30 \%$, b) $40 \%$, c) $50 \%$, d) $60 \%$

pengeringan lebih rendah dibandingkan suhu lainnya. Suhu yang tinggi dapat menyebabkan proses case hardening. Suhu yang terlalu tinggi tidak dianjurkan karena suhu yang tinggi dapat merusak komponen aktif yang terkandung dalam rumput laut.

\section{Kurva laju pengeringan terhadap kadar air}

Kurva laju pengeringan terhadap kadar air dapat dilihat pada Gambar 5 dan 6, Pada variasi suhu dan $\mathrm{RH}$ tampak bahwa pada kadar air tinggi, laju pengeringan juga tinggi, dan laju pengeringan menurun seiring berjalannya proses pengeringan. Menurut Thao dan Noohorm (2011) seiring berjalannya proses pengeringan, laju pengeringan menurun karena air yang diuapkan di permukaan bahan semakin sedikit dan mengandalkan perpindahan air dari dalam bahan ke permukaan. Pada variasi suhu, laju pengeringan tertinggi dari suhu yang diujikan hampir sama yaitu pada kisaran $6 \%$ bk/menit. Pada variasi $\mathrm{RH}$, laju pengeringan tertinggi pada $\mathrm{RH}$ rendah mencapai 6-
$7 \% \mathrm{bk} /$ menit. Sedangkan pada $\mathrm{RH}$ tinggi $50 \%$ dan $60 \%$ laju pengeringan tertingginya hanya setengahnya $3.5 \% \mathrm{bk} / \mathrm{menit}$

\section{Model matematika pengeringan $E$. cottonii}

Berdasarkan model yang disusun pada Tabel 5 dan 6, yang diperlihatkan pada model Lewis dan Henderson, semakin rendah $\mathrm{RH}$ maka konstanta pengeringan cenderung semakin besar dan pada suhu yang tinggi konstanta pengeringan cenderung semakin besar. Pada kelembaban yang rendah proses penghilangan air bebas berlangsung lebih cepat dan sedikit hambatan dibandingkan pada kelembaban yang tinggi. Semakin tinggi temperatur udara dan kadar air bahan menyebabkan gaya dorong antara kandungan air di dalam bahan dan di udara makin besar sehingga cenderung mendorong keluarnya air dari dalam bahan sehingga difusifitas air makin besar, selanjutnya dapat meningkatkan besarnya konstanta pengeringan (Istadi et al., 2002) 
Tabel 5. Model dan konstanta pengeringan lapis tipis pada suhu $50^{\circ} \mathrm{C}$ Table 5. Model and drying coefficient of thin layer drying at temperature $50^{\circ} \mathrm{C}$

\begin{tabular}{|c|c|c|c|c|c|}
\hline Model & RH (\%) & $\mathbf{k}$ & $\mathbf{a}$ & $\mathbf{n}$ & Persamaan /equation \\
\hline \multirow{4}{*}{ Lewis } & 30 & 0.01100 & & & $\operatorname{Ln}(M R)=-0.011 t$ \\
\hline & 40 & 0.01000 & & & $\operatorname{Ln}(M R)=-0.01 t$ \\
\hline & 50 & 0.00800 & & & $\operatorname{Ln}(M R)=-0.008 t$ \\
\hline & 60 & 0.00600 & & & $\operatorname{Ln}(M R)=-0.006 t$ \\
\hline \multirow{4}{*}{$\begin{array}{l}\text { Henderson } \\
\text { \& Pabis }\end{array}$} & 30 & 0.01300 & 1.768 .267 & & $\operatorname{Ln}(M R)=-0.013 t+\ln (1.768267)$ \\
\hline & 40 & 0.01200 & 2.190 .216 & & $\operatorname{Ln}(M R)=-0.012 t+\ln (2.190216)$ \\
\hline & 50 & 0.00900 & 1.714 .292 & & $\operatorname{Ln}(M R)=-0.009 t+\ln (1.714292)$ \\
\hline & 60 & 0.00700 & 1.698 .932 & & $\operatorname{Ln}(M R)=-0.007 t+\ln (1.698932)$ \\
\hline \multirow{4}{*}{ Page } & 30 & 0.00515 & & 1.125 & $\ln [-\ln (\mathrm{MR})]=\ln (0.00515)+1.125 \ln (\mathrm{t})$ \\
\hline & 40 & 0.00286 & & 1.206 & $\ln [-\ln (M R)]=\ln (0.00286)+1.206 \ln (t)$ \\
\hline & 50 & 0.00372 & & 1.125 & $\ln [-\ln (M R)]=\ln (0.00372)+1.125 \ln (t)$ \\
\hline & 60 & 0.00266 & & 1.114 & $\ln [-\operatorname{In}(\mathrm{MR})]=\ln (0.00266)+1.114 \ln (\mathrm{t})$ \\
\hline
\end{tabular}

Tabel 6. Model dan konstanta pengeringan lapis tipis E. cottonii pada $\mathrm{RH} 40 \%$ Table 6. Model and drying constanta thin layer drying E. cottonii at RH 40\%

\begin{tabular}{|c|c|c|c|c|c|}
\hline Model & $\begin{array}{c}\text { Suhu/ } \\
\text { Temperature }\left({ }^{\circ} \mathrm{C}\right)\end{array}$ & K & a & $\mathbf{n}$ & Persamaan/equation \\
\hline \multirow{4}{*}{ Lewis } & 40 & 0.008000 & & & $\ln (\mathrm{MR})=-0.008 \mathrm{t}$ \\
\hline & 50 & 0.010000 & & & $\ln (M R)=-0.01 t$ \\
\hline & 60 & 0.012000 & & & $\ln (M R)=-0.012 t$ \\
\hline & 70 & 0.010000 & & & $\ln (M R)=-0.01 t$ \\
\hline \multirow{4}{*}{$\begin{array}{l}\text { Henderson \& } \\
\text { Pabis }\end{array}$} & 40 & 0.009000 & 1.604 .801 & & $\ln (M R)=-0.09 t+\ln (1.604801)$ \\
\hline & 50 & 0.013000 & 2.332 .638 & & $\ln (M R)=-0.013 t+\ln (2.33263)$ \\
\hline & 60 & 0.014000 & 2.081 .315 & & $\ln (M R)=-0.014 t+\ln (2.081315)$ \\
\hline & 70 & 0.012000 & 1.858 .928 & & $\ln (M R)=-0.012 t+\ln (1.858928)$ \\
\hline \multirow{4}{*}{ Page } & 40 & 0.004883 & & 1.073 & $\ln [-\ln (M R)=\ln (0.00488)+1.073 \ln (t)$ \\
\hline & 50 & 0.002792 & & 1.211 & $\ln [-\ln (M R)=\ln (0.00279)+1.211 \ln (t)$ \\
\hline & 60 & 0.002590 & & 1.256 & $\ln [-\ln (M R)=\ln (0.00259)+1.256 \ln (t)$ \\
\hline & 70 & 0.003739 & & 1.162 & $\ln [-\ln (M R)=\ln (0.003739)+1.162 \ln (t)$ \\
\hline
\end{tabular}

Pengkorelasian model Newton, model Henderson \& Pabis dan model Page yang sesuai dengan data hasil eksperimen menunjukkan bahwa model Page merupakan model yang paling sesuai dengan karakteristik pengeringan lapisan tipis $E$. cottonii, yang diujikan dengan variasi $\mathrm{RH}$ dan suhu. Nilai $\mathrm{R}^{2}$ pada model Page tertinggi dibandingkan model lainnya yang berkisar pada 0,98-0,99, dan nilai $R^{2}$ terkoreksi adalah 0,96 pada variasi $\mathrm{RH}$ dan 0,98 pada variasi suhu. Dengan RMSE yang sangat rendah berkisar antara 0,0002-0,0206 dan nilai SSE 0,0002-0,0126.

Meskipun nilai rata-rata RMSE model Page pada variasi kelembaban sedikit lebih tinggi $(0,02)$ dibandingkan model Lewis dan nilai rata-rata SSE model Page pada variasi suhu lebih tinggi $(0,01)$ dibandingkan model Lewis, namun model Page tetap paling sesuai karena nilai $R^{2}$ sebagai pedoman utama yang dimiliki model tersebut tertinggi $(0,99)$ untuk kedua variasi (suhu dan $\mathrm{RH}$ ) sedangkan RMSE dan SSE yang diperolehnya sangat rendah yang merupakan data pendukung.

Berdasarkan validasi model diketahui bahwa ada $99 \%$ data yang berada pada model Page $\left(R^{2}\right)$, namun dengan mempertimbangkan ketidakpastian pengukuran suhu sebesar $1 \%$ dan $\mathrm{RH}$ sebesar 3\% $\left(R^{2}\right.$ terkoreksi) dan adanya pembesaran error dapat 


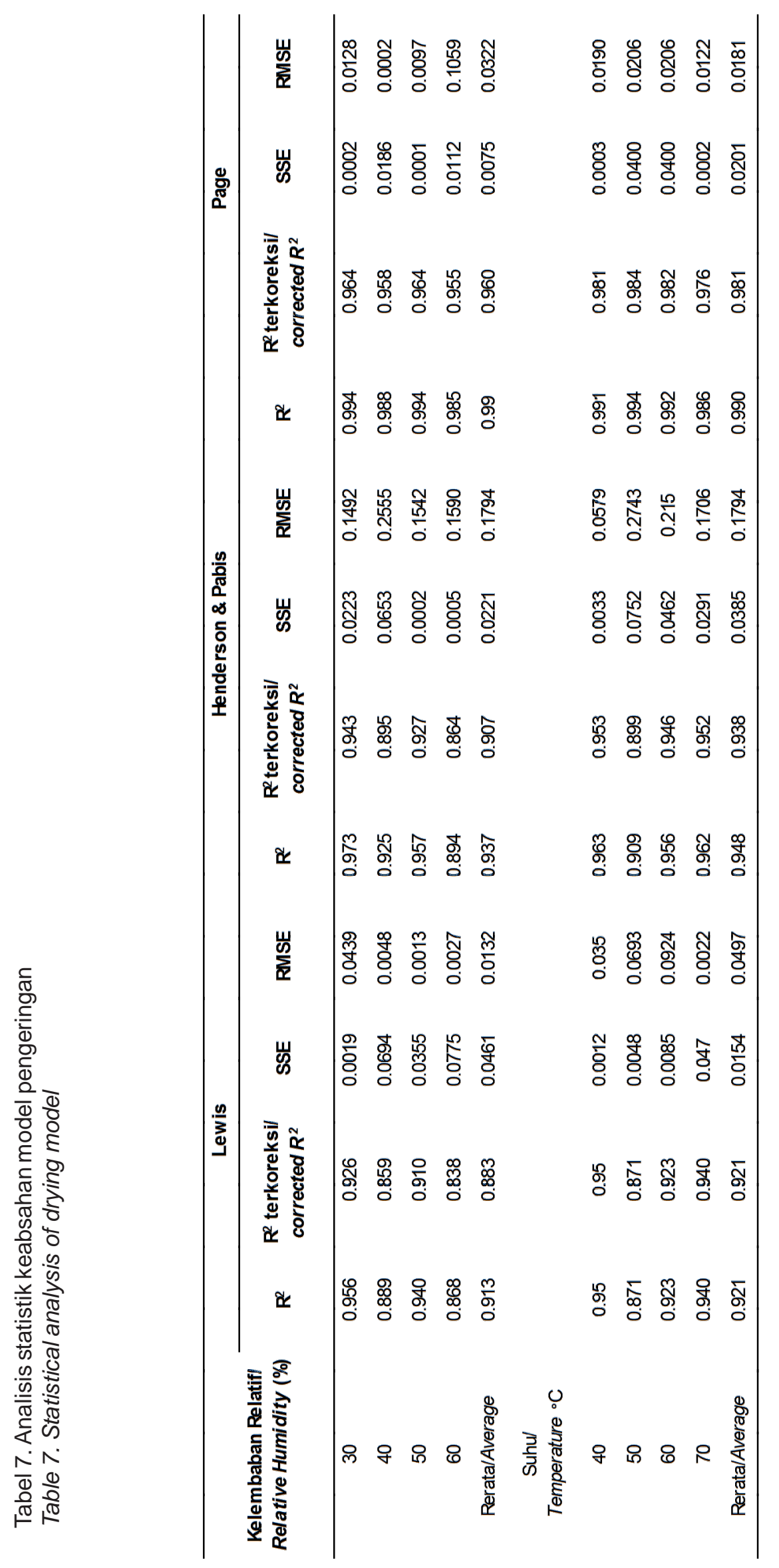




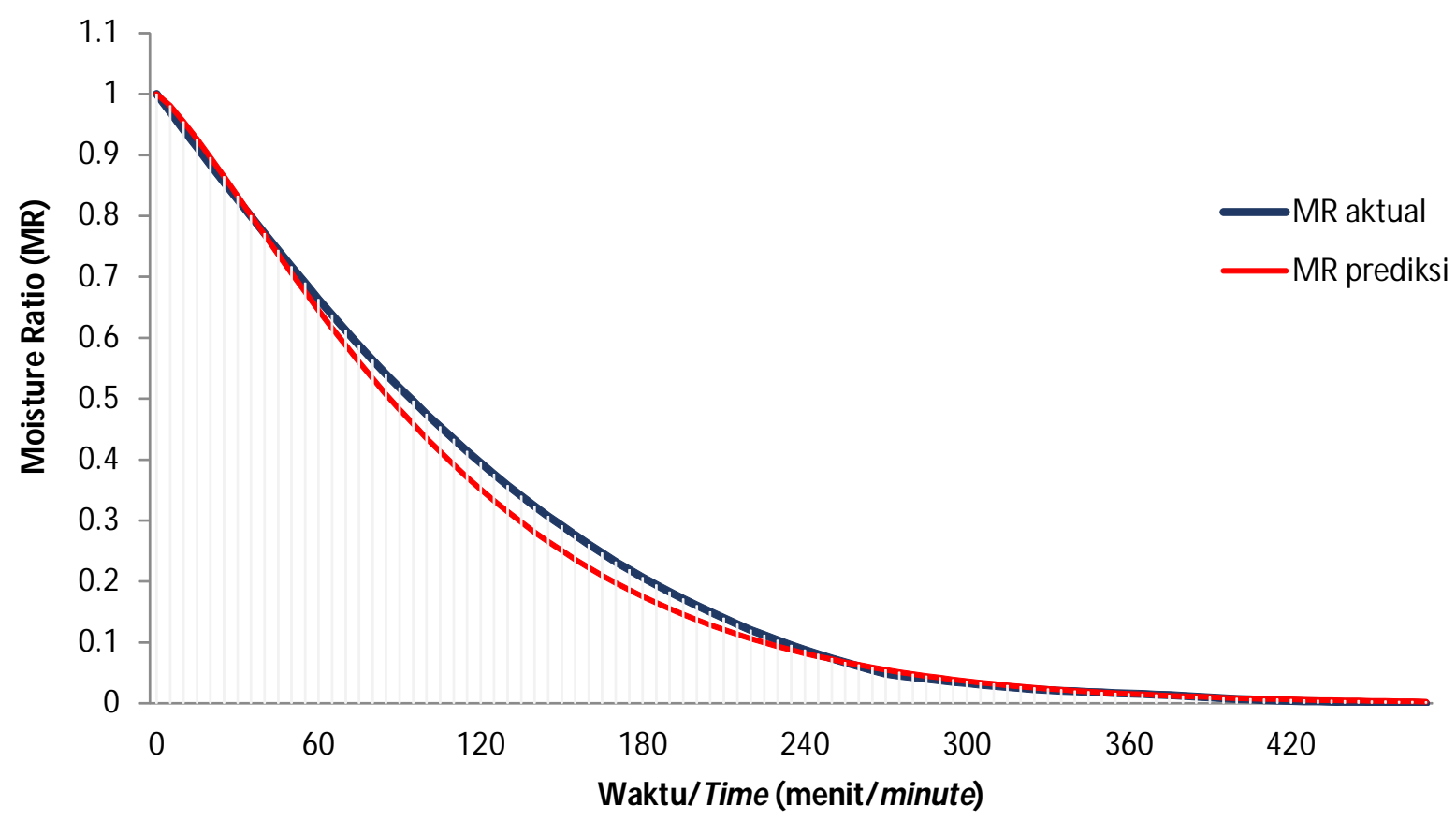

Gambar 7. Kurva pengeringan model matematika E. cottonii pada suhu $60^{\circ} \mathrm{C}$ dan $\mathrm{RH} 40 \%$

Figure 7. Drying curve matematic model of E. cottonii at temperature $60^{\circ} \mathrm{C}$ and $\mathrm{RH} 40 \%$.

dikatakan bahwa tingkat kepercayaan pada model Page yang dihasilkan secara umum adalah di atas $90 \%$.

Gambar 7. merupakan salah satu contoh aplikasi penggunaan model matematika dalam membuat kurva pengeringan MR E. cottonii, hasil perbandingan MR aktual yang diperoleh dengan MR prediksi, di mana data yang digunakan adalah data MR aktual pada suhu $60^{\circ} \mathrm{C}$ dan $\mathrm{RH} 40 \%$,dan MR prediksi merupakan hasil penggunaan persamaan model Page dengan konstanta-konstanta yang diperoleh dari penelitian ini yaitu $\ln [-\ln (\mathrm{MR})=\ln (0,00259)+1,256 \ln (\mathrm{t})($ Tabel 6$)$. Dari Gambar 7 tampak bahwa kurva MR prediksi sangat mendekati dengan kurva MR aktual sehingga dapat dikatakan bahwa model Page ini cocok sebagai model matematika pengeringan rumput laut $E$. cottonii.

\section{KESIMPULAN DAN SARAN}

Laju pengeringan lapis tipis rumput laut $E$. cottonii umumnya berada pada periode laju menurun. Hal ini sesuai dengan karakteristik pengeringan bahan-bahan biopolimer yang umumnya berlangsung dengan laju menurun. Hasil kajian ini menginformasikan bahwa model matematika pengeringan rumput laut yang paling sesuai adalah model Page dengan nilai $R^{2}$ berkisar pada 0,98-0,99, dan nilai $R^{2}$ terkoreksi adalah 0,96 pada variasi $\mathrm{RH}$ dan 0,98 pada variasi suhu. RMSE berkisar antara 0,0002-0,0206 dan nilai SSE 0,0002-0,0126.
Model matematika yang dihasilkan dalam penelitian ini terbatas penggunaannya pada $\mathrm{RH}$ dan suhu yang sama dengan penelitian ini, untuk mengetahui model persamaan pada suhu dan $\mathrm{RH}$ yang berbeda dari penelitian ini perlu dilakukan penelitian lebih lanjut.

\section{DAFTAR PUSTAKA}

Aghabashlo, M., Kianmehr, M.H., \& Khani, S. (2008). Mathematical modeling of carrot thin layer drying using new model. Energy Conversion and Management, 49, 201-212.

Akanbi, C.T., Adeyemi, R.S., \& Ojo, A. (2006) Drying characteristics and sorption isotherm of tomato slices. Journal of Food Engineering, 73, 157-163.

Akpinar, E. K., Midilli, A. \& Bicer, Y. (2003). Single layer drying behaviour of potato slices in a convective cyclone dryer and mathematical modeling. Energy Conversion and Management, 44 (10), 1689-1705.

Akpinar, E. K. (2006). Determination of suitable thin layer drying curve model for some vegetables and fruits. Journal of Food Engineering, 73, 75-84.

[BSN]. Badan Standardisasi Nasional. (2006). Standar Nasional Indonesia Analisis Kadar Air pada produk perikanan (SNI 01-2354.2-2006). Jakarta

Chen, X. D. \& Mujumdar, A. S. (2009). Drying Technologies in Food Processing. New York: John Wiley \& Sons.

Cronin, K. \& Kearney, S. (1998). Monte Carlo modeling of a vegetable tray dryer. Journal of Food Engineering, $35,233-250$. 
Doymaz, L. (2012). Evaluation of some thin-layer drying models of persimmon slices (Diospyroskaki L.). Energy Conversion and Management, 56, 199-205.

Duc, L. A., Han, J. W., Keumb, \& Keum, D. H. (2011). Thin layer drying characteristics of rapeseed (Brassica napus L.). Journal of Stored Products Research, 47, 32-38.

Fudholi, A., Othman, M. Y., Ruslan, M. H., Yahya, M., Zaharim, A., \& Sopian, K. (2011). The effectsof drying air temperature and humidity on drying kinetics of seaweed. Recent Research in Geography, Geology, Energy, Environment and Biomedicine, Corfu, 129133.

Goyal, R. K., Kingsly, A. R. P., Manikantan, M. R. \& llyas, S. M. (2007). Mathematical modelling of thin layer drying kinetics of plum in a tunnel dryer. Journal of Food Engineering, 79, 176-180.

Gupta, P., Ahmet, J., Shivhare, U. S., \& Raghavan, G. S. V. (2002). Drying characteristics of red chilli. Drying Technology, 20 (10), 1975-1987.

Hawa, L. C., Sumardi, H. S., \& Sari, E. P. (2009). Penentuan karakteristik pengeringan lapisan tipis ikan kembung (Rastrelliger sp.) Jurnal Teknologi Pertanian, 10 (3), 153-161.

Ibrahim, M., Sopian, K., \& Daud, W.R.W. (2009). Study of the Drying Kinetics of Lemon Grass . American Journal of Applied Sciences, 6 (6), 1070-1075.

Istadi, Sumardiono, S., \& Soestrisnasnto, D. (2002). Penentuan Konstanta Pengeringan dalam Sistem Pengeringan Lapis Tipis (Thin Layer Dring). Prosiding Seminar Nasional Teknologi Proses Kimia. Inovasi Produk Berkelanjutan, Hotel Sahid Jaya Jakarta.

Kaleta, A., \& Gornicki, K. (2010). Some remarks on evaluation of drying models of red beet particle. Energy Conversion and Management, 51, 2967-2978.

Kashaninejad, M., Mortazavi, A., Safekordi, A., \& Tabil, L. G. (2007). Thin-layer drying characteristics and modeling of pistachio nuts. Journal of Food Engineering, 78, 98-108.

Karimi, F. (2010). Applications of super Heated steam for the drying of food products. Int. Agrophysics, 24, 195-204.

Krokida, M. K., Maroulis, Z. B., \& Kremalis, C. (2002). Process design of rotary dryers for olive cake. Drying Technology, 20(4-5), 771-788.

Kabganian, R., Carrier, D. J., \& Sokhansanj, S. (2002). Physical characteristics and drying rate of Echinacea root. Drying Technology, 20(3), 637-649.
Meisami-asl, E., \& Rafiee, S. (2009). Mathematical modeling of kinetics of thin-layer drying of apple (var. Golab). Agricultural Engineering International: the CIGR Ejournal. Manuscript, 1185.

McHugh, D. J. (2006). The Seaweed Industry in The Pacific Islands. ACIAR Working Paper, 61:55 pp.

Midilli, A., Kucuk, H. \& Yapar, Z. (2002). A new model for single layer drying. Drying Technology, 20 (7),15031513.

Saeed, I. E., Sopian, K., \& Abidin, Z. (2008). Drying characteristics of roselle (1): mathematical modeling and drying experiments. Agricultural Engineering International: the CIGR Ejournal. Manuscript FP 08 015. Vol.X.

Setiyo, Y. (2003) Aplikasi Sistem Kontrol Suhu dan Pola Aliran Udara Pada Alat Pengering Tipe Kotak untuk Pengeringan BuaH Salak, Pengantar Falsafah Sains.Program Pasca Sarjana,Institut Pertanian Bogor.

Setyopratomo, P. (2012). Model matematika pengeringan lapis tipis. Berkala IImiah Teknik Kimia , 1 (1) , 5459.

Sinha, N., Hui, Y. H., Özgül, E., Siddiq, M., \& Ahmed, J. (2010). Handbook of Vegetables and Vegetable Processing.John Wiley \& sons.

Taheri-Garavanda, A., Rafieea, S., \& Keyhania, A. (2011). Mathematical modeling of thin layer drying kineticsof tomato influence of air dryer conditions. International Transaction Journal of Engineering,Management, \& Applied Sciences \& Technologies, 2 (2), 147-160.

Thao, H. M., \& Noomhorm, A. (2011). Modelling and effects of various dying methods on sweet potato starch properties. Walailak J., Sci., Technol., 8, 139158.

Tulek, Y. (2011). Drying kinetics of oyster mushroom (pleurotus ostreatus) in a convective hot air dryer. J. Agr. Sci. Tech., 13, 655-664.

Yadollahinia, A.R., Omid, M., \& Rafiee, S. (2008) . Design and Fabrication of Experimental Dryer for Studying Agricultural Products. Int. J. Agri.Bio., 10, 61-65.

Yaldýz, O., \& Ertekýn, C. (2001). Thin layer solar drying of some vegetables. Drying Technology, 19, 583-596.

Wibowo, S., Peranginangin,R., Darmawan, M., \& Hakim, A.R. (2014). Teknik Pengolahan ATC dari Rumput Laut Eucheuma cottonii. ISBN(13) 978-979-002-668-1. p. 76, Penebar Swadaya. 